\title{
Weed Control in Conservation Agriculture
}

\author{
Andrew Price ${ }^{1}$ and Jessica Kelton ${ }^{2}$ \\ ${ }^{1}$ United States Department of Agriculture \\ ${ }^{2}$ Auburn University \\ United States
}

\section{Introduction}

Prior to the introduction of the selective herbicide, 2,4-D (2,4-dichlorophenoxyacetic acid), in the 1940's, weed control in agricultural crops was primarily achieved through mechanical cultivation of the soil. Since that time, an increasing number of effective herbicide options, paired with tillage operations, have allowed agricultural producers in developed countries to significantly increase crop yields while reducing labor demands. Continuation of these practices that rely on intense soil disturbance, however, have helped fuel concerns over agricultural sustainability in light of the severe soil degradation that occurs under these conditions. In response to continued soil depletion and other environmental impacts from agricultural production, conservation agriculture has been promoted as a means of maintaining high crop productivity and increasing economic potential while preserving natural resources and limiting future environmental damage. To achieve goals proposed with conservation agriculture, innovative weed control strategies including chemical methods have and will continue to be an essential component in the development of sustainable agricultural practices.

An understanding of the fundamental components of conservation agriculture is imperative in order to appreciate the necessity for weed control strategies in these practices as well as the difficulties associated with their development. To that aim, our purpose, in part, is to identify the key components of conservation systems and the evolution of herbicide needs within these practices. Secondly, we present the strategy of high-residue cereal cover crop implementation that can be utilized in conjunction with chemical weed control methods to address the changes in weed control requirements in agricultural settings. Finally the research synopses detail recent and ongoing efforts to ensure the availability of effective herbicide applications within conservation agriculture.

\section{Defining conservation agriculture}

As the global population expands, food demands placed on agricultural production systems will test the capabilities of current agriculture practices. Moreover, adequate food production in the future can only be achieved through the implementation of sustainable growing practices that minimize environmental degradation and preserve resources while maintaining high yielding, profitable systems. To this end, conservation agriculture is a system designed to achieve agricultural sustainability by improving the biological functions of the agroecosystem with limited mechanical practices and judicious use of chemical inputs (FAO, 2010). 
Three core elements of conservation agriculture make possible the objectives of this system including minimal tillage operations, permanent vegetative residue for soil cover, and rotation of primary crops (FAO, 2010). From these components, a more narrow focused system has been defined as conservation tillage which seeks to reduce, although not necessarily eliminate, tillage practices and increase residual soil covering, which may not be permanently maintained, to achieve similar goals as conservation agriculture (Hobbs, 2007). While sometimes mistakenly used synonymously, it is the less intensive conservation tillage system that has become more recognized, and adopted, within the agricultural community.

A host of benefits can be achieved through employing components of conservation agriculture or conservation tillage, including: reduced soil erosion and water runoff, increased productivity through improved soil quality, increased water availability, increased biotic diversity and reduced labor demands (Steiner et al., 2000; Hobbs, 2007). Despite both environmental and production advantages offered through conservation systems, adoption rates have previously lagged in many countries due to several factors including: availability of required equipment, lack of information, producer mindsets, and, initially, weed control issues (Kells and Meggitt, 1985; Derpsch and Friedrich, 2009). However, recent estimates of global adoption rates of no-tillage systems have reported a substantial increase in hectares (ha) under these practices up to 105 million ha in 2008 worldwide from 45 million ha a decade ago (Derpsch and Friedrich, 2009). This increase in conservation practices can partially be attributed to increased awareness of benefits provided through conservation systems and the growing need for agricultural sustainability, but recent technological advancements and refined implementation strategies have also afforded growers an opportunity to adopt these practices with greater confidence and ease.

Presently, research in conservation practices continues to offer innovative strategies for applying conservation systems in many landscapes, climates, and crop settings, in developed or developing countries. Continued efforts to improve adoption rates as well as address current issues, such as herbicide resistance, are necessary to ensure that the global agricultural productivity can be maintained for future generations.

\section{Herbicide requirements in conservation systems}

The shift from conventional tillage practices, where the soil is turned prior to planting, to conservation practices, where tillage is reduced to a minimum, can be particularly difficult with respect to weed control. Successful weed control requires a producer's attention throughout the season in order to achieve an optimal harvest. In systems with intense tillage operations, growers can obtain early season weed control through turning of the soil which disrupts weed seed germination and seedling growth through burial (Steckel et al., 2007). The use of selective herbicide applications over the top of the crop at a later date can, most often, sufficiently reduce weed pressure until the end of the season. In cases where there is a history of a difficult to control weed species emerging, producers have the option to use a preemergent, soil applied herbicide with residual efficacy to further reduce weed germination. Although weed control in tilled systems is no small task, conservation systems have presented an even greater challenge to achieve the same results until recently.

Many weed species within agricultural settings are able to flourish when intense tillage operations are minimized. Therefore, conservation systems have been characterized by greater weed densities than conventionally tilled agricultural productions (Cardina et al, 
2002; Sosnoskie et al., 2006). With reduced tillage practices, producers have increasingly relied on herbicide control options to obtain satisfactory crop yields; however, the initial availability of effective herbicide formulations was limited for conservation tillage. With a reduction in tillage, producers lose weed control offered from seed burial as well as the option to incorporate soil applied preemergent herbicides. Moreover, soil applied herbicides that do not require incorporation can have reduced persistence and efficacy in the presence of plant residue that may intercept and bind the chemical before it reaches the soil surface (Potter et al., 2008). This loss of control options has forced producers wishing to adopt conservation practices to be primarily dependent upon postemergent chemical applications which, oftentimes, fail to provide adequate weed control. To further complicate attempts to adopt conservation practices, growers initially face shifts in weed population dynamics due to altered distribution of weed seed within the soil (Buhler, 1997); perennial weed species also thrive in reduced-tillage settings and can be difficult to control with available postemergent herbicide options (Swanton et al., 1993). Although studies report that, over time, the weed seedbank, or viable weed seed within the soil, will be reduced and/or easier to manage with chemical controls due to increased selection pressures and increased uniform germination, initial weed control strategies have remained challenging for agricultural lands being switched to conservation tillage practices (Murphy et al., 2006; Swanton et al., 2008).

The introduction and advances with herbicide-tolerant crops made in the last 15 years have greatly altered the herbicide needs in conservation systems for those who use these technologies; however in developing regions with limited access to herbicide options or in areas where herbicide-resistant weed species have compromised the use of herbicidetolerant crops in conservation systems, early weed management tactics and control issues in reduced tillage practices remain relevant for growers.

\section{Introduction of herbicide resistant crops}

In the 1990's when transgenic, herbicide-tolerant crops were first introduced, reducedtillage, in the United States at least, became a viable option for many producers. The availability of transgenic crops with resistance to a nonselective herbicide, such as glyphosate, has provide the means for effective postemergent herbicide control of a broad spectrum of weed species while reducing labor demands and repeated herbicide applications. By combining this crop technology with conservation tillage, producers have been able to further reduce labor expenses and boost profitability. Partly through the combination of these practices, conservation tillage has been implemented on over 26 million hectares to date in the United States alone (Derpsch and Friedrich, 2009).

The process of developing and commercializing a transgenic crop cultivar is a complex and costly endeavor which has limited commercial availability of genetically modified crop varieties. For the development of a transgenic crop, particularly an herbicide-tolerant crop, to be pursued, several factors must be investigated including: spectrum of weed control provided by the herbicide, safety risks to humans and the environment, yield performance of genetically modified crop, and economic value of the crop (Devine, 2005). Currently, only a select few herbicide-tolerant crops have been fully developed, marketed, and remain commercially available although the technology exists to produce tolerant varieties for many major and minor crops throughout the world (Devine, 2005)(Table 1). 


\begin{tabular}{|c|cc|}
\hline \multirow{2}{*}{} & \multicolumn{2}{|c|}{ Herbicide } \\
\cline { 2 - 3 } & Glufosinate & Glyphosate \\
\hline Crop & \multicolumn{2}{|c|}{ Year Commercialized } \\
\hline Canola & 1995 & 1996 \\
Corn & 1997 & 1998 \\
Cotton & 2004 & 1997 \\
Soybean & 2009 & 1996 \\
\hline
\end{tabular}

Table 1. Currently available transgenic crops by herbicide tolerance and year available.

Since identifying selective herbicide compounds that are active on weed species and not on a particular crop can be a difficult process, conferring herbicide tolerance of a non-selective herbicide to a crop can be tremendously valuable for effective weed control (Mazur and Falco, 1989). From the non-selective herbicides available for use, two key herbicides have been the focus for herbicide-tolerant crops: glufosinate and glyphosate (Devine, 2005).

The broad spectrum herbicide, glyphosate ( $N$-(phosphonomethyl)glycine), works through the inhibition of 5-enolpyruvylshikimate-3-phosphate synthase (EPSPS), an enzyme required for the production of aromatic amino acids which are necessary for subsequent production of plant hormones and structural components (Schönbrunn et al., 2001; Dill, 2005). The means for conferring glyphosate resistance to crops is achieved through the insertion of a resistant transgene, referred to as CP4-EPSPS, which allows the plant's shikimate pathway to continue to function in the presence of glyphosate applications (Funke et al., 2006). Since the release of glyphosate-tolerant soybean (Glycine max L.) in 1996, adoption of this technology has soared in several industrialized countries, such as the United States, Argentina, and Brazil, and represents a majority of the soybean being produced in these areas (Dill, 2005). The introduction of other major crops with glyphosate tolerance soon followed with successful adoption due to the weed control efficacy, ease of use, and lower production costs from reduced herbicide applications.

Glufosinate, or L-Phosphinothricin, also a non-selective herbicide, acts as an inhibitor of glutamine synthetase which impedes the production of amino acids and inhibits photosynthesis (Dröge-Laser et al., 1994; Ross and Lembi, 1999). Glufosinate-tolerant plant varieties are produced through the encoding for phosphinothricin acetyltransferase (PAT) proteins which detoxify glufosinate through $\mathrm{N}$-acetylation (Dröge et al., 1992; Hérouet et al., 2005). Glufosinate-tolerant canola (Brassica napus L.) was introduced in Canada in 1995 with relative success (Devine, 2005; Duke, 2005). Other tolerant crop varieties have been successfully released since that time but have yet to gain as large of a market share as glyphosate-tolerant varieties potentially due to economic advantages not being realized and the lack of translocation of glufosinate which can limit its efficacy for certain weed species (Duke, 2005).

With the availability of effective broad-spectrum weed control without tillage operations and repeated use of herbicides, conservation tillage saw substantial increases after the introduction of herbicide-tolerant crop varieties. Employing the use of herbicide-tolerant 
crops with conservation systems offered growers even greater costs savings than utilizing either practice alone and continue to do so today. The adoption of glyphosate-tolerant crops was especially suited to conservation systems since glyphosate can effectively control many perennial species that appear when tillage practices are reduced (Ross and Lembi, 1999). Glyphosate-tolerant crops provided such effective control, the use of glyphosate, due, in part, to biotechnology, has become the predominant herbicide used globally (Baylis, 2000). Unfortunately, the cost effectiveness and weed control advantages, paired with limited herbicide choices (primarily in conservation tillage), of glyphosate-tolerant technology have compelled some growers in conventional as well as reduced-tillage systems to rely solely on this herbicide for agricultural productivity. Because of this, in some regions, the sustainability of both conservation tillage and glyphosate use has been threatened due to this overdependence and development of glyphosate resistance in multiple weed species.

\section{Herbicide resistance in weed species}

As early as the 1950's, shortly after widespread herbicide use began, concerns were being voiced about the possibility of herbicide-resistant weed biotypes appearing as a result of repeated exposure to one herbicide (Appleby, 2005). It was not until 1970, however, that the first case of herbicide resistance was formally documented in triazine-resistant common groundsel (Senecio vulgaris L.) (Ryan, 1970). Since that time, 346 herbicide-resistant weed biotypes have been reported worldwide and continue to demand considerable research attention to control existing resistance as well as to combat the further spread of resistant populations (Appleby, 2005; Heap, 2010).

Although almost all herbicide modes of action have seen resistance development, the introduction of glyphosate-tolerant crops has been a prominent factor to the development of glyphosate-resistant weed species for this herbicide (Powles and Yu, 2010). The steady adoption rate of herbicide-tolerant crops has been met with a simultaneous increase in the use glyphosate applications, particularly in conservation systems where minimal herbicide alternatives exist (Askew and Wilcut, 1999; Dill, 2005; Duke and Powles, 2008). The initial success of this weed control strategy has lead many producers to rely exclusively on this single herbicide mode of action to maintain acceptable weed control year after year (Green, 2007). Unfortunately, repeated exposure to glyphosate has greatly increased selection pressure for resistant weed biotypes among affected populations resulting in agricultural weed infestations with limited or no known control options at present (Culpepper, 2006). Rapid development of herbicide resistance is evident in the number of confirmed cases of glyphosate resistance since 1996 which has appeared in 18 different weed species and on all agriculturally productive continents (Figure 1).

From the beginning of glyphosate use in 1974 as a nonselective herbicide in nonagricultural settings, it was believed that resistance development would be highly unlikely or very slow in appearance if it did occur (Bradshaw et al., 1997). At the time, naturally resistant weed species had not been identified, modifications to confer resistance resulted in low levels that could not survive glyphosate applications or reduced the plant's fitness level, and typical use patterns did not increase selection pressure for resistant biotypes (Dyer, 1994; Padgette et al., 1995; Bradshaw et al., 1997). Indeed, glyphosate use successfully utilized without incident for over 2 decades before a resistant biotype of rigid ryegrass (Lolium rigidum Gaudin) was identified in 1996 (Powles et al., 1998). However, since the release of herbicide- 
tolerant crops, several resistant weed biotypes have been reported in glyphosate-tolerant systems in as little as 3 years (Green, 2007; Duke and Powles, 2008).

Mechanisms for herbicide resistance development vary greatly depending on many factors such as weed species and herbicide in use. When resistance emerges, it can be classified as either target-site resistance, where modifications to the active site for an herbicide limits its toxicity, or non-target-site resistance, where herbicide movement to the active site is limited in some fashion (Powles and $\mathrm{Yu}, 2010$ ). Identified resistance mechanisms for glyphosate are comprised of both classifications of resistance, including target-site modifications, gene amplification, as well as reduced herbicide translocation (Lee and Ngim, 2000; LorraineColwill et al., 2003; Gaines et al., 2010). It is likely that new mechanisms for glyphosate resistance will continue to be discovered within current herbicide practices which will require intensified research in order to develop innovative management practices that preserve glyphosate use in many agricultural settings (Powles and $\mathrm{Yu}, 2010$ ).

Managing for herbicide resistance remains a key component in current developments for weed control. Proactive weed control practices that reduce initial resistance development are vital for herbicide viability in the future (which is necessary for sufficient agricultural production). In order to ensure sustainability in herbicide-tolerant crop production and conservation practices, many weed control techniques are currently being employed and evaluated.

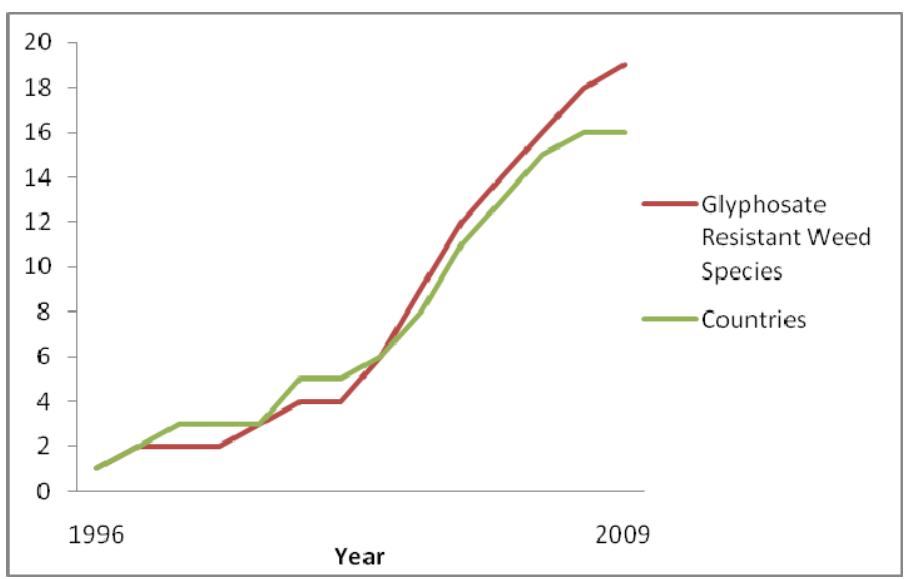

Fig. 1. Global development and spread of glyphosate resistant weed species. Adapted from Heap 2010.

\section{High-residue cereal cover cropping}

The continued appearance of herbicide-resistant weed species following the introduction of herbicide-resistant crops has been detrimental to conservation tillage systems where feasibility relies on this technology. In an effort to preserve conservation tillage and, subsequently, the benefits realized through these practices, current research has been directed at identifying alternative weed control strategies that can be employed in herbicideresistant crop settings, which remain a valuable asset to conservation tillage practices, while minimizing favorable conditions for resistance development. Options for weed control must 
reduce selection pressure for herbicide resistance as well as provide season long weed suppression in order to be viable components of a new weed control strategy. Alternatives to repeated use of a single herbicide include: crop rotation, improved management practices (such as weed scouting and herbicide application timing), alternative herbicide chemistries, and use of high-residue cover crop systems (Price et al., 2009). Ideal alternative growing practices would incorporate several of these strategies to protect against resistance development, however, the use of a particular practice, high-residue cover cropping, is proving to be an exceptional weed control technique in conservation systems.

Recent evaluations of cereal cover crop use, particularly high residue systems that achieve approximately 4,500 kilograms of residue per hectare (Reiter et al., 2008), have demonstrated a promising method for battling herbicide dependence and providing a sustainable approach for the continuation of conservation tillage (Figure 2). The high-residue cover crop system, when utilized in a reduced-tillage system, can further reduce soil erosion and water runoff, improve soil fertility, and, with legume covers, reduce nitrogen input needs. These winter cereal crops or legumes can also improve weed control through both physical barriers of plant residue and chemical interference in the form of allelopathic compounds released by the cover crop. Although concerns have been raised about the potential for reduced crop yields and increased need for more herbicide applications, research continues to show that these practices can be successfully implemented into conservation tillage (Balkcom and Reeves, 2005; SAN, 2007; Price et al., 2008; Reiter et al., 2008).

A variety of options are available to a producer wishing to utilize a winter cover crop between the primary growing season depending on the crops grown, climate, and needs of the system. For example, legume cover crops, such as clover (Trifolium sp.) and vetch (Vicia $s p$.), can potentially reduce nitrogen requirements for the following crop but may not provide season-long weed control; cereal cover crops, like rye (Secale cereale L.) and oat (Avena sp.), can provide longer weed control throughout the season can also reduce available soil nitrogen (SAN, 2007). Besides legume and cereal crops, brassica and mustard species are also of interest for cover crop use due to their potential for pest management.

Cover crops can reduce weed numbers physically and chemically while actively growing or after termination. Prior to termination, cover crops can compete with weed species for necessary resources such as light, water, and nutrients; cover crops can also release allelochemicals into the soil which may be detrimental to nearby competing weed species, particularly for small-seeded weeds (Weston, 1996; Foley, 1999; Price et al., 2008). After termination, weed suppression occurs by physical impedance of weed species with cover crop residue as well as continued leaching of allelochemicals into the soil (Weston, 1996). These characteristics allow cover crops to offer early weed control as well as weed suppression into the growing season (depending on the rate of decomposition).

Although the use of cover crops in production systems is a viable option for producers, there are still concerns that must still be investigated. High-residue cover crops, before termination, can deplete soil moisture needed by the primary crop (SAN, 2007); conversely, dense plant residue can retain excessive amounts of moisture during periods of high rainfall (Fernandez et al., 2008). Lower soil temperatures, increased plant pest populations, as well as planting operation interferences, such as poor soil-to-seed contact, have also been attributed to high levels of cover crop residue (Fernandez et al., 2008; Kornecki et al., 2009). Additionally, high levels of plant residue are thought to impede herbicide movement to the soil surface through interception and sorption leading to reduced weed control under cover 
crop systems (Johnson et al., 1989; Gaston et al., 2003). Future adoption of these practices will be dependent upon continued research in many areas but especially in determining effective herbicide strategies to be employed in combination with high-residue systems.

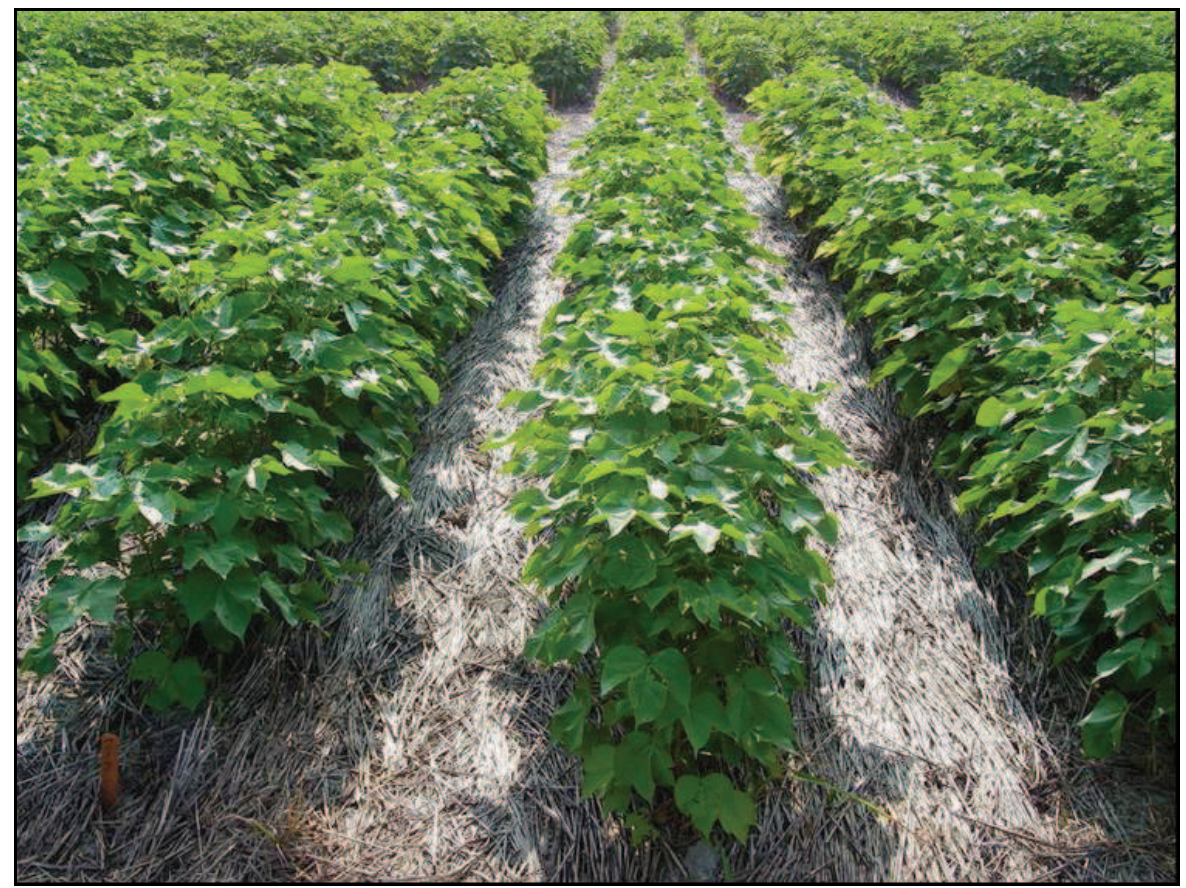

Fig. 2. Cotton (Gossypium hirsutum L.) planted into a soil cover of black oat (Avena strigosa Schreb.).

\section{Development of effective weed control strategies for use in conservation systems}

The growing adoption rate of conservation practices and interest of high-residue cover crops has spawned an increase in research geared toward understanding the fit of herbicides into the sustainable agricultural landscape. Case studies described here illustrate recent projects in three major crop systems designed to determine the most effective production practices, including herbicide choice, that can be employed for successful adoption of high residue cover crop systems which will ultimately aid in reducing herbicide resistance and preserve sustainable agricultural practices for the future.

Peanut (Arachis hypogaea L.), cotton, and soybean comprise a substantial portion of the agricultural hectarage in the southeastern United States. A large percentage of growers in this region utilize some form of conservation tillage due to its economic benefits such as reduced labor and fuel expense. Use of cover crops managed for high-residue in these systems remains largely untried due to grower concerns about herbicide input requirements and poor yields (Schwab et al., 2002). To investigate these concerns, a three year study was conducted in Headland, Alabama, in the southeastern US, to determine the effects of a 
winter cereal cover crop on primary crop yield as well as to identify effective herbicide practices (Price et al., 2005; Reeves et al., 2005; Price et al., 2007).

In order to achieve high-residue stands, three winter covers, rye, wheat (Triticum aestivum L.), and black oat (Avena strigosa Schreb.), were established in November at a rate of $120 \mathrm{~kg} / \mathrm{ha}$ with $56 \mathrm{~kg}$ ammonium nitrate and terminated three weeks prior to planting of the primary crop in the spring of the following year. A winter fallow system of annual weeds was included as a comparison and as a representation of the common conservation practice by regional producers. After termination with glyphosate as a burndown herbicide at a rate of $1.12 \mathrm{~kg}$ ae/ha, cover crops were rolled flat on the surface with a mechanical roller-crimper.

Crops were planted into a strip-tilled bed that limits tillage to a small area, approximately 30 $\mathrm{cm}$, for seed placement. Three herbicide treatments were included for evaluation and consisted of a preemergence (PRE) herbicide application only (low input system), a PRE plus a postemergence (POST) herbicide application (high input system), or no herbicide application (no input system). Peanut and cotton received pendimethalin [N-(1ethylpropyl)-3,4-dimethyl-2,6-dinitrobenzenena-amine] as a PRE at a rate of $1.12 \mathrm{~kg}$ ai/ha and soybean received this herbicide treatment at a rate of $0.84 \mathrm{~kg}$ ai/ha. Additional PRE herbicides included metribuzin [4-amino-6-(1,1-dimethylethyl)-3-(methylthio)-1,2,4-triazin$5(4 H)]$ at $0.43 \mathrm{~kg}$ ai/ha for soybean and fluometuron [1,1-dimethyl-3-(a,a,a-triluoro-m-toly) urea] at $1.7 \mathrm{~kg}$ ai/ha for cotton. Postemergent herbicides included: paraquat (1,1'-Dimethyl4,4'-bipyridynium dichloride) (0.14 kg ai/ha), bentazon [3-(1-methylethyl)-1H-2,1,3benzothiadiadiazin-4(3H)-one 2,2-dioxide] (0.56 kg ai/ha), 2,4-DB [4-(2,4-dichlorophenoxy) butyrate] $(0.22 \mathrm{~kg}$ ai/ha), and chlorimuron ethyl \{ethyl 2-[[[[(4-chloro-6-methoxypyrimidin$2 \mathrm{yl}$ )] carbonyl]amino]sulfonyl]benzoate $\}$ (0.14 $\mathrm{kg}$ ai/ha) for peanut; DSMA (Disodium methanearsonate) (1.7 kg ai/ha), lactofen \{2 ethoxy-1-methyl-2-oxoethyl 5-[2-chloro-4(trifluoromethyl)phenoxy]-2-nitrobenzoate $(0.2 \mathrm{~kg}$ ai/ha) and cyanazine \{2-[[4-chloro-6(ethylamino)-1,3,5-triazin-2-yl]amino]-2-methylpropanenitrile\} (0.84 $\mathrm{kg}$ ai/ha) for cotton; and chlorimuron ethyl $(8.75 \mathrm{~g}$ ai/ha) for soybean. Herbicide options reflect current herbicide use in the respective crop.

At cover crop termination, biomass samples were weighed for each cover. First year results averaged $5,450 \mathrm{~kg} / \mathrm{ha}$ for black oat, $5,130 \mathrm{~kg} / \mathrm{ha}$ for rye, $5,100 \mathrm{~kg} / \mathrm{ha}$ for wheat, and 1,410 $\mathrm{kg} / \mathrm{ha}$ for fallow systems with the predominant weed species being cutleaf evening primrose (Oenothera laciniata Hill) and chickweed [Stellaria media (L.) Vill.]. Biomass residue levels for all cover crops in this year exceeded amounts considered the minimum for highresidue systems. Averages for cover crop weights were in line with previously reported biomass weights (Bauer and Reeves, 1999).

Visual weed control ratings (as a percentage of control) for year 1 are presented in Table 2. Dominant weed species in research plots for all crops included: large crabgrass [Digitaria sanguinalis (L.) Scop.], Texas panicum (Panicum texanum Buckl.), nutsedges (Cyperus esculentus L. and Cyperus rotundus L.), sicklepod [Senna obtusifolia (L.) Irwin and Barnaby], and Palmer amaranth [Amaranthus palmeri (S.) Wats.]. Analysis of data revealed significant effects on weed control from both cover crop and herbicide input treatments. Although no cover crop provided optimum season-long weed control without herbicide applications, black oat and rye did provide substantial weed control in peanut and soybean without herbicides; low herbicide input treatments, however, had acceptable weed control in peanut and soybean, especially in black oat and rye covers. In years 2 and 3 (data not shown), weed 
control was reduced in all covers, particularly black oat, due to below-average winter temperatures inhibiting cover crop growth and biomass production. Crop yields in cover crop systems were increased over fallow systems for all crops, however, yields were greatly reduced in systems without any herbicide application (Table 3). Increases in yield noted in cover crops systems over fallow systems are attributed to reduced weed pressure as well as other benefits from conservation systems that are amplified when high-residue cover crops are employed such as increased water infiltration and increased soil quality.

Results from this study show that high-residue cover crop systems can be effectively utilized in conservation systems with increased yield potential and possible reductions in herbicide inputs for adequate weed control. Reduced herbicide dependence, without yield decrease, can ultimately aid in reduced herbicide-resistance development and sustain conservation tillage practices well into the future. For high-residue cover crops to be more widely adopted, research continues to be necessary to fully understand the benefits, and potential drawbacks, of their use at a regional level as well as to define the most effective cover crop choices for producers in a variety of systems.

\begin{tabular}{|c|c|c|c|c|c|c|c|c|c|}
\hline \multirow[b]{3}{*}{ Cover crop } & \multicolumn{3}{|c|}{ Cotton } & \multicolumn{3}{|c|}{ Peanut } & \multicolumn{3}{|c|}{ Soybean } \\
\hline & \multicolumn{3}{|c|}{ Herbicide input system } & \multicolumn{3}{|c|}{ Herbicide input system } & \multicolumn{3}{|c|}{ Herbicide input system } \\
\hline & High & Low & None & High & Low & None & High & Low & None \\
\hline & \multicolumn{3}{|c|}{----Weed control (\%)--- } & \multicolumn{3}{|c|}{----Weed control (\%)--- } & \multicolumn{3}{|c|}{----Weed control (\%)--- } \\
\hline Fallow & 94 & 86 & 13 & 91 & 88 & 24 & 92 & 85 & 29 \\
\hline Black oat & 95 & 91 & 35 & 93 & 94 & 70 & 95 & 95 & 86 \\
\hline Rye & 94 & 89 & 26 & 94 & 93 & 61 & 95 & 95 & 83 \\
\hline Wheat & 94 & 87 & 14 & 94 & 93 & 43 & 95 & 91 & 61 \\
\hline
\end{tabular}

Table 2. Weed control for year 1 in cotton, peanut, and soybean by percent control for four cover crop options and three herbicide inputs (by intensity) where 100 is total control and 0 is no control.

\begin{tabular}{|c|c|c|c|c|c|c|c|c|c|}
\hline \multirow[b]{3}{*}{$\begin{array}{c}\text { Cover } \\
\text { crop }\end{array}$} & \multicolumn{3}{|c|}{ Cotton } & \multicolumn{3}{|c|}{ Peanut } & \multicolumn{3}{|c|}{ Soybean } \\
\hline & \multicolumn{3}{|c|}{ Herbicide input system } & \multicolumn{3}{|c|}{ Herbicide input system } & \multicolumn{3}{|c|}{ Herbicide input system } \\
\hline & High & Low & None & High & Low & None & High & Low & None \\
\hline & \multicolumn{3}{|c|}{---Seed cotton $(\mathrm{kg} / \mathrm{ha})----$} & \multicolumn{3}{|c|}{---Peanut (kg/ha)--- } & \multicolumn{3}{|c|}{---Soybean (kg/ha)--- } \\
\hline Fallow & 3660 & 3010 & 0 & 4280 & 4100 & 2030 & 4031 & 4031 & 1344 \\
\hline $\begin{array}{c}\text { Black } \\
\text { oat }\end{array}$ & 3840 & 3630 & 0 & 4760 & 4740 & 3190 & 6719 & 7391 & 6047 \\
\hline Rye & 3980 & 3350 & 0 & 4690 & 4850 & 3460 & 6047 & 6719 & 6047 \\
\hline Wheat & 3970 & 3120 & 0 & 4670 & 4420 & 2500 & 6719 & 6719 & 4703 \\
\hline
\end{tabular}

Table 3. Crop yield for year 1 as affected by three herbicide inputs and four cover crop options. No yield could be collected for cotton without herbicide input. 


\section{Conclusions}

Conservation systems are necessary to preserve agricultural productivity and meet future global food demands. To implement these systems, adequate weed control is crucial in their success. Herbicide use has been a valuable asset when adopting conservation practices, however, prudent use of chemical weed control is essential to fulfilling the goals of conservation agriculture, reducing detrimental environmental impact, and reducing herbicide resistance development. Further development and testing of alternative weed management practices that can be utilized along with herbicide applications must be pursued in order for conservation practices to remain successful.

\section{References}

Appleby, A.P. (2005) A history of weed control in the United States and Canada - a sequel. Weed Science, 53, 762-768, ISSN 0043-1745.

Askew, S.D. and J.W. Wilcut (1999) Cost and weed management with herbicide programs in glyphosate-resistant cotton (Gossypium hirsutum). Weed Technology, 13, 308-313, ISSN 0890-037X.

Balkcom, K.S. and D.W. Reeves (2005) Sunn-hemp utilized as a legume cover crop for corn production. Agronomy Journal, 97, 26-31, ISSN 0002-1962.

Bauer, P.J. and D.W. Reeves (1999) A comparison of winter cereal species and planting dates as residue cover for cotton grown with conservation tillage. Crop Science, 39, 18241830, ISSN 0011-183X.

Baylis, A.D. (2000) Why glyphosate is a global herbicide: strengths, weaknesses and prospects. Pest Management Science, 56, 299-308, ISSN 1526-4998.

Bradshaw, L.D., S.R. Padgette, S.L. Kimball, and B.H. Well (1997) Perspectives on glyphosate resistance. Weed Technology, 11, 189-198, ISSN 0890-037X.

Buhler, D.D. (1997) Effects of tillage and light environment on emergence of 13 annual weeds. Weed Technology, 11, 496-501, ISSN 0890-037X.

Cardina, J., C.P. Herms and D.J. Doohan (2002) Crop rotation and tillage system effects on weed seedbanks. Weed Science, 50, 448-460, ISSN 0043-1745.

Culpepper, A.S. (2006) Glyphosate-induced weed shifts. Weed Technology, 20, 277-281, ISSN 0890-037X.

Derpsch, R. and T. Friedrich (2009) Development and current status of no-till adoption in the world. Proceedings on CD, $18^{\text {th }}$ Triennial Conference of the International Soil Tillage Research Organization (ISTRO), June 15-19, 2009, Izmir Turkey.

Devine, M.D. (2005) Why are there not more herbicide-tolerant crops? Pest Management Science, 61, 312-317, ISSN 1526-4998.

Dill, G. M. (2005) Glyphosate-resistant crops: history, status, and future. Pest Management Science 61, 219-224, ISSN 1526-4998.

Dröge W., I. Broer, and A. Pühler (1992) Transgenic plants containing the phosphinothricin$\mathrm{N}$-acetyltransferase gene metabolize the herbicide phosphinothricin (glufosinate) differently from untransformed plants. Planta, 187, 142-1551, ISSN 1432-2048. 
Dröge-Laser, W., U. Siemeling, A. Pühler, and I. Broer (1994) The metabolites of the herbicide L-Phosphinothricin (Glufosinate). Plant Physiology, 105, 159-166, ISSN 1532-2458.

Duke, S.O. and S.B. Powles (2008) Glyphosate: a once-in-a-century herbicide. Pest Management Science, 64, 319-325, ISSN 1526-4998.

Dyer, W.E. (1994) Resistance to glyphosate, In: Herbicide Resistance in Plants, S.B. Powles and J.A.M. Holtum (Eds.), 229-241, Lewis Publishing, ISBN 0873717139, Boca Raton, FL, USA.

Fernandez, R., A. Quiroga, E. Noellemeyer, D. Funaro, J. Montoya, B. Hitzmann, and N. Peinemann (2008) A study of the effect of the interaction between site-specific conditions, residue cover and weed control on water storage during fallow. Agricultural Water Management, 95, 1028-1040, ISSN 0378-3774.

Foley, M.E. (1999) Genetic approach to the development of cover crops for weed management, In: Expanding the Context of Weed Management, D.D. Buhler (Ed.), 7793, The Haworth Press, ISBN 9781560220633, New York, NY, USA.

Food and Agriculture Organization of the United Nations (FAO) (2010) Available online at http://www.fao.org/ag/ca/index.html (verified 20/7/10).

Funke, T., H. Han, M. L. Healy-Fried, M. Fischer, and E. Schönbrunn (2006) Molecular basis for the herbicide resistance of Roundup Ready crops. Proceedings of the National Academy of Sciences, 35,13010-13015, ISSN 1091-6490.

Gaines, T.A., W. Zhang, D. Wang, B. Bukun, S.T. Chisholm, D.L. Shaner, S.J. Nissen, W.L. Patzoldt, P.J. Tranel, A.S. Culpepper, T.L. Grey, T.M. Webster, W.K. Vencill, R.D. Sammons, J. Jiang, C. Preston, J.E. Leach, and P. Westra (2010) Gene amplification confers glyphosate resistance in Amaranthus palmeri. Proceedings of the National Academy of Sciences, 107, 1029-1034, ISSN 1091-6490.

Gaston, L.A., D.J. Boquet, and M.A. Bosch (2003) Pendimethalin wash-off from cover crop residues and degradation in a Loessial soil. Communications in Soil Science and Plant Analysis, 34, 2515-2527, ISSN 0010-3624.

Green, J.M. (2007) Review of glyphosate and ALS-inhibiting herbicide crop resistance and resistant weed management. Weed Technology, 21, 547-558, ISSN 0890-037X.

Heap, I. (2010) The international survey of herbicide resistant weeds. Available online at http://www.weedscience.com (verified 28/7/10).

Hérouet, C., D.J. Esdaile, B.A. Mallyon, E. Debruyne, A. Schulz, T. Currier, K. Hendrickx, R. van der Klis, and D. Rouan (2005) Safety evaluation of the phosphinothricin acetyltransferase proteins encoded by the pat and bar sequences that confer tolerance to Glufosinate-ammonium herbicide in transgenic plants. Regulatory Toxicology and Pharmacology, 41, 134-149, ISSN 0273-2300.

Hobbs, P.R. (2007) Conservation agriculture: what is it and why is it important for future sustainable food production? Journal of Agricultural Science, 145, 127-137, ISSN 00218596.

Johnson, M.D., D.L. Wyse, and W.E. Lueschen (1989) The influence of herbicide formulation on weed control in four tillage systems. Weed Science, 37, 239-249, ISSN 0043-1745. 
Kells, J.J. and W.F. Meggitt (1985) Conservation tillage and weed control, In: A Systems Approach to Conservation Tillage, F.M. D’Itri (Ed.), 123-129, Lewis Publishing, ISBN 087371024X, Chelsea, MI, USA.

Kornecki, T.S., A.J. Price, R.L. Raper, and F.J. Arriaga (2009) New roller crimper concepts for mechanical termination of cover crops in conservation agriculture. Renewable Agriculture and Food Systems, 24, 165-173, ISSN 1742-1713.

Lee, L.J. and J. Ngim (2000) A first report of glyphosate-resistant goosegrass (Eleusine indica (L) Gaertn) in Malaysia. Pest Management Science, 56, 336-339, ISSN 1526-4998.

Lorraine-Colwill, D.F., S.B. Powles, T.R. Hawkes, P.H. Hollinshead, S.A.J. Warner, and C. Preston (2003) Investigation into the mechanism of glyphosate resistance in Lolium rigidum. Pesticide Biochemistry and Physiology, 74,62-72, ISSN 0048-3575.

Mazur, B.J. and S.C. Falco (1989) The development of herbicide resistant crops. Annual Review of Plant Physiology and Plant Molecular Biology, 40, 441-470, ISSN 1040-2519.

Murphy, S.D., D.R. Clements, S. Belaoussoff, P.G. Kevan, and C.J. Swanton (2006) Promotion of weed species diversity and reduction of weed seedbanks with conservation tillage and crop rotation. Weed Science, 54, 69-77, ISSN 0043-1745.

Padgette, S.R., K.H. Kolac, X. Delannay, D.B. Re, B.J. Lavallee, C.N. Tinius, W.K. Rhodes, Y.I. Otero, G.F. Barry, and D.A. Eicholtz (1995) Development, identification, and characterization of glyphosate-tolerant soybean line. Crop Science, 35, 1451-1461, ISSN 0011-183X.

Potter, T.L., C.C. Truman, T.C. Strickland, D.D. Bosch, and T.M. Webster (2008) Herbicide incorporation by irrigation and tillage impact on runoff loss. Journal of Environmental Quality, 37, 839-847, ISSN 0047-2425.

Powles, S.B., D.F. Lorraine-Colwill, J.J. Dellow, and C. Preston (1998) Evolved resistance to glyphosate in rigid ryegrass (Lolium rigidum) in Australia. Weed Science, 46, 604-607, ISSN 0043-1745.

Powles, S.B. and Q. Yu (2010) Evolution in action: plants resistant to herbicides. Annual Review of Plant Biology, 61, 317-347, ISSN 1543-5008.

Price, A.J., D.W. Reeves, and M.G. Patterson (2005) Evaluation of weed control provided by three winter cereals in conservation-tillage soybean. Renewable Agriculture and Food Systems, 21, 159-164, ISSN 1742-1713.

Price, A.J., D.W. Reeves, M.G. Patterson, B.E. Gamble, K.S. Balkcom, F.J. Arriaga, and C.D. Monks (2007) Weed control in peanut grown in a high-residue conservation-tillage system. Weed Science, 34, 59-64, ISSN 0043-1745.

Price, A.J., M.E. Stoll, J.S. Bergtold, F.J. Arriaga, K.S. Balkcom, T.S. Kornecki, and R.L. Raper (2008) Effect of cover crop extracts on cotton and radish radical elongation. Communications in Biometry and Crop Science, 3, 60-66, ISSN 1896-0782.

Price, A.J., D.W. Reeves, and D.A. Lamm (2009) Glyphosate resistant Palmer amaranth-a threat to conservation tillage. Proceedings of the Beltwide Cotton Conference, January 5-8, San Antonio, TX, USA.

Reiter, M.S., D.W. Reeves, C.H. Burmester, H.A. Torbert (2008) Cotton nitrogen management in a high-residue conservation system: Cover crop fertilization. Soil Science Society of America Journal, 72, 1321-1329, ISSN 1435-0661. 
Reeves, D.W., A.J. Price, and M.G. Patterson (2005) Evaluation of three winter cereals for weed control in conservation-tillage nontransgenic cotton. Weed Technology, 19, 731736, ISSN 0890-037X.

Ross, M.A. and C.A. Lembi (1999) Applied Weed Science, Prentice-Hall, ISBN 0137540035, Upper Saddle River, NJ, USA.

Ryan, G.F. (1970) Resistance of common groundsel to simazine and atrazine. Weed Science, 18, 614-616, ISSN 0043-1745.

Schönbrunn, E., S. Eschenburg, W.A. Shuttleworth, J.V. Schloss, N. Amrhein, J.N. Evans, and W. Kabsch (2001) Interaction of the herbicide glyphosate with its target enzyme 5-enolpyruvylshikimate 3-phosphate synthase in atomic detail. Proceedings of the National Academy of Science 98, 1376-1380, ISSN 1091-6490.

Schwab, E.B., D.W. Reeves, C.H. Burmester, and R.L. Raper (2002) Conservation tillage systems for cotton in the Tennessee Valley. Soil Science Society of America Journal, 66, 142-153, ISSN 0361-5995.

Sosnoskie, L.M., C.P. Herms and J. Cardina (2006) Weed seedbank community composition in a 35-yr-old tillage and rotation experiment. Weed Science, $54,263-\quad 273, \quad$ ISSN 0043-1745.

Steckel, L.E., C.L. Sprague, E.W. Stoller, L.M. Wax, and F.W. Simmons (2007) Tillage, cropping system, and soil depth effects on common waterhemp (Amaranthus rudis) seed-bank persistence. Weed Science, 55, 235-239 ISSN 0043-1745.

Steiner, J.L., H.H. Schomberg, P.W. Unger, and J. Cresap (2000) Biomass and residue cover relationships of fresh and decomposing small grain residue. Soil Science Society of America Journal, 64, 2109-2114, ISSN 1435-0661.

Sustainable Agriculture Network (SAN) (2007) Managing Cover Crops Profitably. $3^{\text {rd }}$ edition. A. Clark (Ed.), ISBN 978888626124, Beltsville, MD, USA.

Swanton, C.J., D.R. Clements, and D.A. Derksen (1993) Weed succession under conservation tillage: A hierarchical framework for research and management. Weed Technology, 7 , 286-297, ISSN 0890-037X.

Swanton, C.J., K.J. Mahoney, K. Chandler, and R.H. Gulden (2008) Integrated weed management: Knowledge-based weed management systems. Weed Science, 56, 168172, ISSN 0043-1745.

Weston, L.A. (1996) Utilization of allelopathy for weed management in agroecosystems. Agronomy Journal, 88, 860-866, ISSN 0002-1962. 


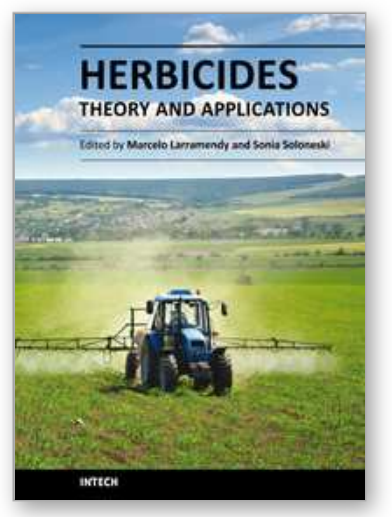

\author{
Herbicides, Theory and Applications \\ Edited by Prof. Marcelo Larramendy
}

ISBN 978-953-307-975-2

Hard cover, 610 pages

Publisher InTech

Published online 08, January, 2011

Published in print edition January, 2011

The content selected in Herbicides, Theory and Applications is intended to provide researchers, producers and consumers of herbicides an overview of the latest scientific achievements. Although we are dealing with many diverse and different topics, we have tried to compile this "raw material" into three major sections in search of clarity and order - Weed Control and Crop Management, Analytical Techniques of Herbicide Detection and Herbicide Toxicity and Further Applications. The editors hope that this book will continue to meet the expectations and needs of all interested in the methodology of use of herbicides, weed control as well as problems related to its use, abuse and misuse.

\title{
How to reference
}

In order to correctly reference this scholarly work, feel free to copy and paste the following:

Andrew Price and Jessica Kelton (2011). Weed Control in Conservation Agriculture, Herbicides, Theory and Applications, Prof. Marcelo Larramendy (Ed.), ISBN: 978-953-307-975-2, InTech, Available from:

http://www.intechopen.com/books/herbicides-theory-and-applications/weed-control-in-conservation-agriculture

\section{INTECH}

open science | open minds

\author{
InTech Europe \\ University Campus STeP Ri \\ Slavka Krautzeka 83/A \\ 51000 Rijeka, Croatia \\ Phone: +385 (51) 770447 \\ Fax: +385 (51) 686166 \\ www.intechopen.com
}

\author{
InTech China \\ Unit 405, Office Block, Hotel Equatorial Shanghai \\ No.65, Yan An Road (West), Shanghai, 200040, China \\ 中国上海市延安西路65号上海国际贵都大饭店办公楼 405 单元 \\ Phone: +86-21-62489820 \\ Fax: $+86-21-62489821$
}


(C) 2011 The Author(s). Licensee IntechOpen. This chapter is distributed under the terms of the Creative Commons Attribution-NonCommercialShareAlike-3.0 License, which permits use, distribution and reproduction for non-commercial purposes, provided the original is properly cited and derivative works building on this content are distributed under the same license. 